ISSN 1392-3196 / e-ISSN 2335-8947

Zemdirbyste-Agriculture, vol. 102, No. 3 (2015), p. 313-318

DOI 10.13080/z-a.2015.102.040

\title{
Yield and economic return response of silage maize to different levels of irrigation water in a sub-humid zone
}

\author{
Abdullah KARASU, Hayrettin KUŞÇU, Mehmet ÖZ \\ Mustafakemalpasa Vocational School, Uludag University \\ Bursa, Turkey \\ E-mail: akarasu@uludag.edu.tr
}

\begin{abstract}
Field studies were conducted during the summers of 2007 and 2008 to determine the response of silage maize (Zea mays L.) to different levels of irrigation water to guide programs for the development of improved irrigation management practices for sub-humid zones. The experiments were carried out in Bursa, Marmara region, Turkey. Silage maize plants (cv. 'Ada-523') were subjected to different levels of irrigation using a drip system in the field on a clay-loam soil. Fully irrigated $(\mathrm{FI}=100 \%)$ plants were irrigated at $100 \%$ pan evaporation (Epan) replenishment with 7-day intervals. In other treatments, irrigation was applied as excessive (EI $=125 \%$ Epan) and deficit $(\mathrm{DI}-75=$ $75 \%$ Epan, DI-50 $=50 \%$ Epan, DI-25 $=25 \%$ Epan, NI - no irrigation). Plant height, first ear height, stem diameter, number of ears per plant and net income decreased with decreases in the amount of irrigation, but the effect of soil water deficit on the number of leaves per plant and ear ratio in forage was minor. The highest forage yields were obtained with EI (125\% Epan), FI (100\% Epan) and DI-75 (75\% Epan) treatments. FI treatment produced the highest net income based forage yield. Severe soil water deficit substantially reduced forage yields and net income in both years. The results showed that full irrigation during the whole growing season is preferable for higher forage yield and net income. However, in regions of water scarcity, farmers should adopt the deficit irrigation (DI$75=75 \%$, DI-50 $=50 \%$ and DI- $25=25 \%$ Epan) approach to achieve economically sustainable crop production. As an alternative to full irrigation during the entire growing season, the irrigation at a rate of DI-75\% Epan can be recommended as optimal level because it achieved irrigation water savings of $25 \%$, an increase of $16 \%$ in forage yield irrigation water use efficiency, satisfactory crop morphological characters and an acceptable net income with a yield loss of only approximately $7 \%$ compared with full irrigation.
\end{abstract}

Key words: drip irrigation, forage yield, irrigation water use efficiency, net income, water deficit, Zea mays.

\section{Introduction}

Maize is one of the most important cereals both for human and animal consumption and is grown for grain and forage (Steduto et al., 2012). It is widely cultivated as a silage plant throughout the world because of its high yield, high energy forage produced with lower labour and machinery requirements than the other forage crops and it has extensive adaptation ability (Allen et al., 1995; Iqbal et al., 2014). The Marmara region is one of the important regions in Turkey, both for plant and animal breeding. Animal growers in this region sometimes feed their animals with cereal straw, which has not enough nutrition. Therefore, it is important to improve plant product with sufficient nutritive value for animal nutrition. Thus, the needs of animal feed for improved cattle farms are very important. A lot of cultivars have been used for the main and second crop silage maize production in Turkey as well as worldwide. Since it has multiple use areas, the land area planted with maize has increased considerably in recent years in Turkey.

Many environmental, cultural and genetic factors influence maize forage yield and quality. Because water is one of the most important environmental factors affecting the growth and production of maize, irrigation scheduling is crucial for increasing maize yield and quality. The irrigation scheduling that determines the timing and amount of irrigation water is governed by many factors, but microclimate plays the most important role (Imtiyaz et al., 2000). According to the literature, maize has high water requirements (Igbadun et al., 2008). It needs different amounts of water at different growing periods. If there is not enough moisture in the soil for emergence, the soil has to be irrigated. Maize is very sensitive to water stress (Rhoads, Bennett, 1990; Pandey et al., 2000; Çakir, 2004; Kuşçu, Demir, 2012). Payero et al. (2009) reported that water stress can affect growth, development and physiological processes of maize plants and reduce biomass yield. Farré and Faci (2009) noted that maize needs the highest water amount during the flowering period. Because of this, one of the most important factors that can limit crop production is availability of water (Genc et al., 2013). If water stress can be avoided during silking and early ear development, the higher forage yield may be expected.

Irrigation water supplies are decreasing in Turkey like in many areas of the world. Although Marmara region in Turkey is located in a sub-humid environment, rainfall is very low in the summer, which is the growing season for maize (average seasonal rainfall for 19602012 is $65 \mathrm{~mm}$ ). The total precipitation does not meet the water requirements of maize crop. Therefore, irrigation is necessary for optimal vegetative and reproductive development in the periods of insufficient precipitation during the growing season in the Marmara region (Kuşçu et al., 2014). Furthermore, the water consumption of maize varies from $500-800 \mathrm{~mm}$ in growing period. Moreover, the other crops need to be irrigated at this period. Therefore, inefficient and expensive water resources must be rationally shared among crops. The furrow and sprinkler irrigation methods are used traditionally for irrigation of maize in Turkey and Marmara Region. However, when we think 
about global warming and drought, the economical use of irrigation water is important for the world and humans. Because of this situation farmers and researchers have to be motivated to find the ways to produce crops with less irrigation water, such as using more efficient irrigation systems and changing from fully-irrigated to deficit irrigated cropping systems (Kuşçu et al., 2014). Farmers think that a higher silage yield could be obtained when excessive water is used. Excessive irrigation is generally seen at regions where there is ample and cheap water. The excessive irrigation causes some social problems among farmers when they do not find enough water for irrigation. Furthermore, excessive irrigation increases the cost of irrigation, causes some environmental and agronomical problems like salinity, erosion and drainage. On the other hand, the limited fresh water resources and the energy cost of pumping water for irrigation are the most important reasons that induced many farmers to decrease irrigation in the Marmara region. This condition is forcing growers and water managers to consider the deficit irrigation option for reducing agricultural water use. In Bursa province, the knowledge of soil-water-yield relationships is particularly important for maize because this crop covers more irrigated area than other crops in the region.

In general, most research on the irrigation of maize is devoted to the study of the grain yield and quality responses to water stress (Çakir, 2004; Farré, Faci, 2009; Payero et al., 2009). Less information is available on deficit irrigation effects on forage yield, quality and water use efficiency of maize (Kızıloglu et al., 2009). However, farmers' primary objective is to maximize their income per cultivated area (Luquet et al., 2005). Before deficit irrigation can be accepted as a management strategy, its effect on yield, quality and net income should be determined based on water-yield relationships and an economic evaluation (Kuşçu et al., 2014).
The purposes of this study were to 1) quantify the forage yield response of silage maize to deficit, full and excessive irrigation in a sub-humid environment, 2) determine irrigation water and yield relationships and irrigation water use efficiency, 3) evaluate the profitability of different levels of irrigation water from an economic perspective, and 4) specify the best deficit irrigation management for reaching the aim of reducing irrigation water use.

\section{Materials and methods}

Field trials were conducted during the growing seasons of 2007 and 2008, at the Agricultural Research Station of Mustafakemalpasa Vocational School, Uludag University in Bursa, Turkey. The coordinates of the trial area are $40^{\circ} 02^{\prime} \mathrm{N}$ and $28^{\circ} 23^{\prime} \mathrm{E}$. Its altitude is $25 \mathrm{~m}$ from the sea level. At the experimental site, soils were classified as Lithosol according to FAO soil classification (Encyclopedia of Soil Science, 2008). The soil texture was clay-loam (average $32.8 \%$ clay, $43.6 \%$ silt and $23.6 \%$ sand content) with $0.15 \%$ total nitrogen $(\mathrm{N})$ content (Kjeldahl method), $0.39 \mathrm{~kg} \mathrm{ha}^{-1}$ exchangeable phosphorus $\left(\mathrm{P}_{2} \mathrm{O}_{5}\right)$ (Olsen method), $1305 \mathrm{~kg} \mathrm{ha}^{-1}$ exchangeable potassium ( $\left.\mathrm{K}_{2} \mathrm{O}\right)$ (ammonium acetate method), 2.1\% organic matter (Walchey-Black method) and a bulk density of $1.41 \mathrm{~g} \mathrm{~cm}^{-3}$. The soil $\mathrm{pH}$ was 7.8. The trial area is located in the southern Marmara region, with an average annual rainfall of $681 \mathrm{~mm}$ and $14^{\circ} \mathrm{C}$ mean monthly temperature. The experimental area has a sub-humid climate. The climatic data for maize growing period of the experimental years are presented in Table 1. Total precipitation from May to September was 77 and $123 \mathrm{~mm}$ in 2007 and 2008, respectively. This approximately matches up to $15 \%$ of the annual rainfall. It is inadequate for maize cultivation as expected.

The hybrid cultivar 'Ada-523' (Agricultural Research Institute, Sakarya, Turkey) was used as plant

Table 1. Mean air temperature, total monthly precipitation, and mean relative humidity in 2007 and 2008, and between 1990 and 2006 in Bursa province, Turkey

\begin{tabular}{|c|c|c|c|c|c|c|c|c|c|}
\hline \multirow{2}{*}{ Month } & \multicolumn{3}{|c|}{$\begin{array}{c}\text { Mean air temperature } \\
{ }^{\circ} \mathrm{C}\end{array}$} & \multicolumn{3}{|c|}{$\begin{array}{c}\text { Total monthly precipitation } \\
\mathrm{mm}\end{array}$} & \multicolumn{3}{|c|}{$\begin{array}{c}\text { Mean relative humidity } \\
\%\end{array}$} \\
\hline & 2007 & 2008 & 1990-2006 & 2007 & 2008 & $1990-2006$ & 2007 & 2008 & 1990-2006 \\
\hline May & 20 & 18 & 17 & 12 & 25 & 43 & 61 & 67 & 65 \\
\hline June & 25 & 23 & 22 & 47 & 11 & 23 & 55 & 63 & 60 \\
\hline July & 26 & 24 & 24 & 13 & 0 & 14 & 51 & 61 & 61 \\
\hline August & 26 & 24 & 23 & 1 & 0 & 15 & 53 & 62 & 62 \\
\hline September & 21 & 20 & 20 & 4 & 87 & 31 & 57 & 76 & 65 \\
\hline Total & - & - & - & 77 & 123 & 126 & - & - & - \\
\hline
\end{tabular}

material in the two seasons. The experimental plot size was $13.0 \mathrm{~m}^{2}(5.0 \times 2.6 \mathrm{~m})$, row distance $-0.65 \mathrm{~m}$, within row spacing $-0.10 \mathrm{~m}$. The seeds were planted to plots on 10 May in 2007 and 17 May in 2008. Prior to sowing, $180 \mathrm{~kg} \mathrm{ha}^{-1} \mathrm{~N}$ and $120 \mathrm{~kg} \mathrm{ha}^{-1} \mathrm{P}_{2} \mathrm{O}_{5}$ were applied to all experimental plots. Weed control was performed by hand twice during the growing season.

In a randomized complete block design with three replications, the following experiments were studied: excessive irrigation $(\mathrm{EI}=125 \%$ pan evaporation (Epan) replenishment), full irrigation ( $\mathrm{FI}=100 \%$ Epan), three different deficit irrigations (DI-75 $=75 \%$ Epan, DI-50 $=50 \%$ Epan and DI-25 $=25 \%$ Epan) and no irrigation (NI). The United States Weather Bureau Class A evaporation pan was used to measure daily evaporation. Irrigation management was based on the common practice in the area for maize, which consists of irrigation at 7-day intervals. Irrigation water was applied by drip irrigation. The water was pumped directly from the Mustafakemalpasa Aquifer to the drip system. The thick-walled drip tape $\left(160 \mathrm{l} \mathrm{h}^{-1} 100 \mathrm{~m}^{-1}\right.$ at a pressure of $100 \mathrm{kPa}$ ) was used for all experiments with pressure-compensating emitters spaced every $0.3 \mathrm{~m}$ and an outer diameter of $16 \mathrm{~mm}$, and they were laid adjacent to each crop row in the plots. During the first two weeks all the treatments in order to establish plants received a total amount of 76 and $91 \mathrm{~mm}$ irrigation water in 2007 and 2008, respectively. The seasonal water applied in treatments EI, FI, DI-75, DI-50, DI-25 and NI were 1042, $850,658,466,274$ and $76 \mathrm{~mm}$, respectively, in the 2007 season experiments, and 985, 806, 627, 448, 269 and $91 \mathrm{~mm}$ for treatments EI, FI, DI-75, DI-50, DI-25 and NI, respectively, in the 2008 season experiments.

Ten plants randomly selected from each plot were collected just prior to the forage harvest to assess morphological characters such as plant height, first ear height, stem diameter, number of ears per plant, ear percentage in the green herbage $(\%)$, and number of leaves per plant. After removing the border effects, two rows of each plot were harvested and weighed fresh in situ to determine the forage yield at the milk-to-dough stage (Carpici, Celik, 2010).

Forage yield irrigation water use efficiency (FYIWUE, $\mathrm{kg} \mathrm{m}^{-3}$ ) was estimated by the following equation (Zhang et al., 1999):

$$
\text { IWUE }=\frac{Y_{\mathrm{i}}-\mathrm{Y}_{0}}{\mathrm{I}_{\mathrm{i}}-\mathrm{I}_{0}},
$$

where $Y_{i}$ is the forage yield for irrigation treatment $\mathrm{i}\left(\mathrm{kg} \mathrm{ha}^{-1}\right), \mathrm{Y}_{0}-$ yield for equivalent dry land (non-irrigated 
treatment, $\left.I_{0}\right), I_{i}$ - seasonal irrigation water applied for treatment $\mathrm{i}\left(\mathrm{m}^{3} \mathrm{ha}^{-1}\right)$ and $\mathrm{I}_{0}$ - amount of irrigation water applied for germination.

An economic analysis was applied to the results of this study based on investment, operation and production costs (Çetin, Uygan, 2008; Kuşçu et al., 2014). The cost of water for each irrigation treatment was calculated by multiplying the cost of a unit volume of water and the total quantity of irrigation water required for the maize crop. All other production costs including labour (installation, irrigation, planting, weeding, cultivation, fertilizer application, spraying and harvesting), land preparation, seeds, fertilizers and chemicals (insecticides and pesticides) were assumed constant across all water treatments. In treatment NI, the cost of drip irrigation system was not considered. Polls and personal interviews were conducted with farmers to obtain information that would specify the crop management procedures (Kuşçu et al., 2009). To calculate the total cost of maize production for one year, the sum of the crop production costs, yearly cost of the irrigation system and irrigation cost were considered (Çetin, Uygan, 2008).

The data were subjected to analyses of variance using $I B M^{\circledR}$ SPSS $^{\circledR}$ Statistics, version 22.0 (SPSS Inc. 2013). Duncan's multiple range test was used to group the means of irrigation levels when the $F$-test was significant. Relationship between seasonal irrigation water applied and forage yield of maize was fitted to the following quadratic equation:

$$
\mathrm{FY}=\mathrm{a}[\mathrm{IWA}]^{2}+\mathrm{b}[\mathrm{IWA}]+\mathrm{c} \text {, }
$$

where FY is forage yield, IWA - seasonal irrigation water applied, a, b, and c are regression parameters. The software SPSS was used to carry out regression analysis.

\section{Results and discussion}

Analysis of variance. The analysis of variance indicated that year significantly affected forage yield and all the morphological characters measured. According to the data combined over two years, irrigation treatments significantly affected all characters except the number of leaves per plant and ear ratio in forage. On the other hand, year $\times$ treatment interactions were significant at $95 \%$ probability level for first ear height and stem diameter, which indicated that treatments responded variously to different years (Table 2). This result indicated that irrigation levels responses were various according to the seasons. Values related to these parameters increased as the irrigation water levels increased. On the other hand, the values obtained from the same irrigation water level at different growing seasons formed different statistical groups.
Morphological characters. The mean values of all characters measured in different irrigation treatments are summarized in Table 2. Irrigation treatments of EI, FI and DI-75 produced the tallest plants (306.9-310.1 $\mathrm{cm})$. Plant height decreased with increasing the severity of deficit irrigation. The shortest $(263.5 \mathrm{~cm})$ plants were obtained from NI treatment. These results indicate that FI and EI significantly increased plant height in maize. Differences in plant height resulted directly in differences in the first ear height among treatments (Table 2). The values of higher first ear height $(139.6-143.1 \mathrm{~cm})$ were observed for treatments of EI, FI, DI-75 and DI-50. Our findings were in total agreement with those of Otegui et al. (1995), Pandey et al. (2000), Istanbulluoglu et al. (2002), Cakir (2004), Bozkurt et al. (2006) and Kuşçu and Demir (2012).

Irrigation treatments also significantly affected stem diameter. FI and EI treatments produced the largestdiameter (16.4-16.8 mm) stems. Stem diameter decreased with increasing the severity of deficit irrigation. The values of stem diameter obtained in this study were lower than those obtained in another study near the research area (Bursa, Turkey) conducted by Kuşç and Demir (2012). This difference may be due to the different plant densities used in the experiments. When the plant density is higher than normal density for maize, the plants compete for the light and have higher plant height, and thus the stem diameter is decreased. The maize with thick stems has higher cellulose, hemicellulose and lignin content, which makes their digestion hard and decrease quality of herbage. But maize with thick stems has higher herbage yield. The quality of maize with thin stem is higher than that of maize with thick stem.

Irrigation treatments had no statistically significant effect on the number of leaves per plant and their average values varied from 14.18 to 15.17 per plant in all treatments (Table 2). These results are contrary to the reports that irrigation increases the number of leaves per plant (Bozkurt et al., 2006; Kuşçu, Demir, 2012). This disagreement may be due to the different maize cultivars used in the experiments (Göksoy et al., 2004).

Within irrigation treatments, the number of ears per plant differed significantly. The EI, FI and DI-75 treatments produced the highest values (in the same group with values of $0.94-0.97$ ), followed by DI-50 with 0.90 . The lowest number $(0.79)$ of ear per plant was obtained from NI treatment. These results indicate that soil water stress significantly affected the number of ears per plant in maize. These results are comparable with the recent findings of Pandey et al. (2000), who demonstrated that a negative trend in response to an increasing soil water deficit was observed for ear number per unit area. This result also agrees with the findings of Çakir (2004).

Table 2. The effects of irrigation treatments on forage yield and certain plant characters (2-year average)

\begin{tabular}{|c|c|c|c|c|c|c|c|}
\hline Treatment & Plant height $\mathrm{cm}$ & $\begin{array}{l}\text { First ear height } \\
\qquad \mathrm{cm}\end{array}$ & Stem diameter mm & $\begin{array}{l}\text { Number } \\
\text { of leaves } \\
\text { per plant }\end{array}$ & $\begin{array}{l}\text { Number } \\
\text { of ears } \\
\text { per plant }\end{array}$ & $\begin{array}{c}\text { Ear ratio } \\
\text { in forage } \\
\%\end{array}$ & $\begin{array}{c}\text { Forage } \\
\text { yield } \\
\mathrm{t} \mathrm{ha}^{-1}\end{array}$ \\
\hline $\mathrm{NI}$ & $263.5 \mathrm{~d}$ & $116.7 \mathrm{c}$ & $14.4 \mathrm{e}$ & 14.18 & $0.79 \mathrm{~d}$ & 33.35 & $55.2 \mathrm{~d}$ \\
\hline DI-25 & $285.6 \mathrm{c}$ & $135.0 \mathrm{~b}$ & $15.0 \mathrm{~d}$ & 14.85 & $0.85 \mathrm{c}$ & 34.42 & $70.9 \mathrm{c}$ \\
\hline DI-50 & $300.2 \mathrm{~b}$ & $139.6 \mathrm{ab}$ & $15.5 \mathrm{c}$ & 15.13 & $0.90 \mathrm{~b}$ & 35.90 & $98.1 \mathrm{~b}$ \\
\hline DI-75 & $306.9 \mathrm{ab}$ & $139.9 \mathrm{ab}$ & $16.0 \mathrm{~b}$ & 14.88 & $0.94 \mathrm{a}$ & 36.38 & $117.0 \mathrm{a}$ \\
\hline FI & $310.6 \mathrm{a}$ & $142.9 \mathrm{a}$ & $16.8 \mathrm{a}$ & 15.17 & $0.97 \mathrm{a}$ & 35.92 & $125.9 \mathrm{a}$ \\
\hline EI & $310.1 \mathrm{a}$ & $143.1 \mathrm{a}$ & $16.4 \mathrm{ab}$ & 15.17 & $0.94 \mathrm{a}$ & 35.15 & $126.0 \mathrm{a}$ \\
\hline Mean & 296.1 & 136.2 & 15.7 & 14.89 & 0.89 & 35.18 & 98.8 \\
\hline \multicolumn{8}{|c|}{ Significance of $F$-ratios } \\
\hline Year $(Y)$ & $* *$ & $* *$ & $* *$ & $*$ & $*$ & $* *$ & $* *$ \\
\hline Treatment $(\mathrm{T})$ & $* *$ & $* *$ & $* *$ & ns & $* *$ & ns & $* *$ \\
\hline $\mathrm{Y} \times \mathrm{T}$ & ns & $*$ & $*$ & ns & ns & $\mathrm{ns}$ & $\mathrm{ns}$ \\
\hline
\end{tabular}

Notes. NI - no irrigation, DI-25 - irrigation at 25\% pan evaporation (Epan) replenishment, DI-50 - irrigation at 50\% Epan, DI-75 irrigation at $75 \%$ Epan, FI - full irrigation $=100 \%$ Epan, EI - excessive irrigation $=125 \%$ Epan. Means followed by the same letter not significantly different at 0.05 level by Duncan's multiple range test. *, ** - significant at $p \leq 0.05$ and 0.01 level, respectively; ns - not significant. 
However, ear number per plant was lower than some results of early researches (Geren et al., 2003; Turgut et al., 2005; Kuşçu, Demir, 2012), because of higher plant density $\left(15.4\right.$ plant $\mathrm{m}^{-2}$ ). In general, the ear ratio in forage was not significantly affected by irrigation levels. The ear ratio in forage values was slightly higher in the first growing season than in the second growing season. The average ear ratio in forage values was $35.18 \%$ over two years (Table 2). The results were also supported by the finding of Turgut et al. (2005).

Forage yield. The FI, EI and DI-75 treatments during the total growing season produced more forage yield. The mean values varied from 117.0 to $126.0 \mathrm{t} \mathrm{ha}^{-1}$ (Table 2). Forage yield significantly reduced as the amount of irrigation decreased. The lowest forage yield $\left(55.2 \mathrm{t} \mathrm{ha}^{-1}\right)$ was obtained from the NI treatment. For that reason, in the case of limited irrigation, severe deficit irrigation during total growing season should be avoided. In addition, year factor with statistically significant forage yields indicated that growing seasons affected forage yield differently. It was found that average forage yield in the first growing season $\left(104.3 \mathrm{tha}^{-1}\right)$ was higher than that of the second growing season $\left(93.4 \mathrm{t} \mathrm{ha}^{-1}\right.$ ) (data not shown in Table 2). The reason may be differences in the amount and distribution of precipitation and differentiation in temperature as the major factors affecting forage yield and some yield components of maize (Geren et al., 2003). In the first growing season of the 2-year study, plant height, stem diameter, the number of leaves per plant were higher, because of this the first growing season's forage yield was higher than that of the second growing season's forage yield (Fig. 1). Bozkurt et al. (2006) reported that full irrigation resulted in significantly higher biomass production. Similarly, the previous studies demonstrated that the lowest green herbage yields were obtained from non-irrigated parcels. Our results were also supported by the findings of Kizıloğlu et al. (2009).

Water-forage yield relationship. Information on water-yield relationship is necessary for efficient water management and economic evaluation (Kuşçu et al., 2014). The relationship of forage yield with seasonal irrigation water applied is shown in Figure 2. The relationship is quadratic $\left(R^{2}=0.95\right)$ for both experimental years, implying that slight amount of irrigation increases forage yield, on average linearly up to a point where the correlation was curved because a portion of the irrigation water applied is probably not used in crop evapotranspiration. At a level of approximately $1121 \mathrm{~mm}$ of irrigation amount, forage yield reached its threshold (average $129 \mathrm{t} \mathrm{ha}^{-1}$ ). Additionally, the regressions show

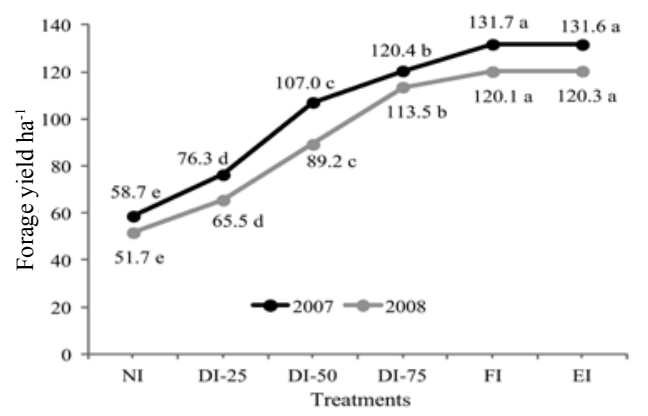

Notes. NI - no irrigation, DI-25 - irrigation at $25 \%$ pan evaporation (Epan) replenishment, DI-50 - irrigation at 50\% Epan, DI-75 - irrigation at 75\% Epan, FI - full irrigation = $100 \%$ Epan, EI - excessive irrigation $=125 \%$ Epan. Means followed by the same letter not significantly different at 0.05 level by Duncan's multiple range test.

Figure 1. Forage yield of the treatments in the experimental years

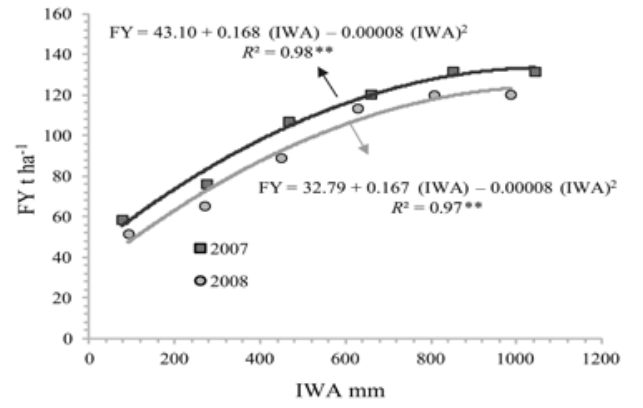

$R^{2}$ - determination coefficient, $* *$ - significance at the $99 \%$ probability level $(P<0.01)$

Figure 2. Forage yield (FY) vs seasonal irrigation water applied (IWA) for combined experimental years

that higher amounts of irrigation did not increase it any further (Fig. 2). Nevertheless, the relationship between forage yield and irrigation water applied is not necessarily quadratic. For example, a linearity between irrigation water applied and forage yield has been reported by Overman and Martin (2002). This situation is closely related to the variability in the amount and temporal distribution of rainfall from year to year during the growing season. The yield response to water may also vary according to the potential crop productivity.

Forage yield irrigation water use efficiency (FYIWUE). Irrigation water use efficiency is an indicator that reflects the efficient use of water resources in plant production. FYIWUE was changed depending on the irrigation treatments (Fig. 3). The lowest FYIWUE values were determined for EI conditions in both growing seasons. On the other hand, moderately deficit irrigation effectively enhanced FYIWUE. Deficit irrigation in level of $75 \%$ and $50 \%$ of crop evapotranspiration (DI-75 and DI-50) produced the highest values of FYIWUE, followed full irrigation treatment in both seasons. However, in contrast to our study, Gheysari et al. (2007) stated that irrigation water use efficiency decreased owing to deficit irrigation for silage maize. This could be explained by the fact that green herbage yield could be affected by factors including cultivar, climate, cultural practices and irrigation management.

Economic return. The price of silage maize and irrigation cost, as well as the effect of water on forage yield and water productivity, should be considered to maximize the profit from irrigation management. The results of an economic evaluation based on averages of two years are shown in Table 3 . The water prices were determined from the amounts of groundwater used by the farmers

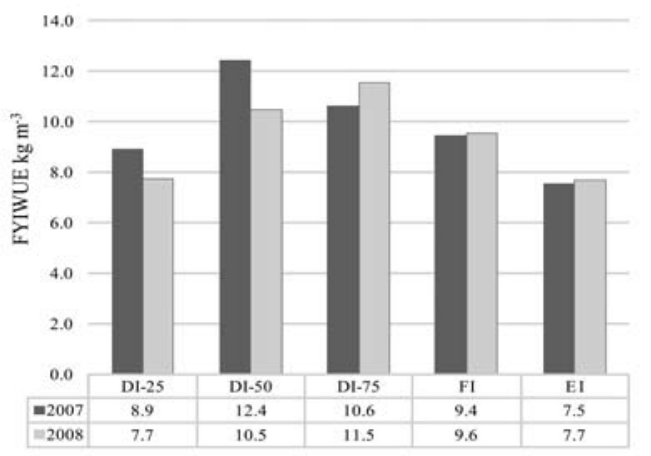

DI-25 - irrigation at $25 \%$ pan evaporation (Epan) replenishment, DI-50 - irrigation at 50\% Epan, DI-75 - irrigation at $75 \%$ Epan, $\mathrm{FI}-$ full irrigation $=100 \%$ Epan, EI - excessive irrigation $=$ $125 \%$ Epan

Figure 3. Forage yield irrigation water use efficiency (FYIWUE) for maize in the two years of experiment 
Table 3. The economic analysis and results for the treatments

\begin{tabular}{|c|c|c|c|c|c|c|c|}
\hline Treatment & $\begin{array}{l}\text { Irrigation } \\
\text { water } \\
\mathrm{m}^{3} \mathrm{ha}^{-1}\end{array}$ & $\begin{array}{l}\text { Irrigation duration } \\
\text { for the irrigation } \\
\text { season } \\
\text { hour ha }^{-1}\end{array}$ & $\begin{array}{l}\text { Labour cost for } \\
\text { irrigation } \\
\$ \text { hour }^{-1}\end{array}$ & $\begin{array}{c}\text { Total cost } \\
\text { for irrigation } \\
\text { labour } \\
\$\end{array}$ & $\begin{array}{l}\text { Water } \\
\text { price } \\
\$ m^{-3}\end{array}$ & $\begin{array}{l}\text { Water } \\
\text { cost } \\
\$ \mathrm{ha}^{-1}\end{array}$ & $\begin{array}{c}\text { Crop production } \\
\text { cost } \\
\$ \text { ha }^{-1}\end{array}$ \\
\hline & $1^{\mathrm{a}}$ & 2 & 3 & $4=2 \times 3$ & 5 & $6=1 \times 5$ & 7 \\
\hline NI & 835 & 10.2 & 1.8 & 18.4 & 0.15 & 125.3 & 3521 \\
\hline DI-25 & 2715 & 33.1 & 1.8 & 59.6 & 0.15 & 407.3 & 3521 \\
\hline DI-50 & 4570 & 55.7 & 1.8 & 100.3 & 0.15 & 685.5 & 3521 \\
\hline DI-75 & 6425 & 78.3 & 1.8 & 141.0 & 0.15 & 963.8 & 3521 \\
\hline FI & 8280 & 100.9 & 1.8 & 181.6 & 0.15 & 1242.0 & 3521 \\
\hline EI & 10135 & 123.5 & 1.8 & 222.3 & 0.15 & 1520.3 & 3521 \\
\hline Treatment & $\begin{array}{c}\text { Irrigation } \\
\text { system cost } \\
\text { for } 1 \mathrm{ha} \\
\$ \mathrm{ha}^{-1}\end{array}$ & $\begin{array}{l}\text { Yearly cost of the } \\
\text { irrigation system } \\
\qquad \mathrm{ha}^{-1}\end{array}$ & $\begin{array}{l}\text { Total cost } \\
\text { for } 1 \text { year } \\
\$ h^{-1}\end{array}$ & $\begin{array}{l}\text { Forage yield } \\
\mathrm{kg} \mathrm{ha}^{-1}\end{array}$ & $\begin{array}{c}\text { Forage sale } \\
\text { price } \\
\$ \mathrm{~kg}^{-1}\end{array}$ & $\begin{array}{l}\text { Gross income } \\
\text { per ha } \\
\$ \text { ha }^{-1} \text { year }\end{array}$ & $\begin{array}{c}\text { Net } \\
\text { income } \\
\$ \text { ha }^{-1} \text { year }^{-1}\end{array}$ \\
\hline & 8 & $9=8-7$ years & $10=4+6+7+9$ & 11 & 12 & $13=11 \times 12$ & $14=13-10$ \\
\hline $\mathrm{NI}$ & 0 & 0 & 3664.6 & 55200 & 0.07 & 3864 & 199 \\
\hline DI-25 & 4500 & 642.9 & 4630.7 & 70870 & 0.07 & 4961 & 330 \\
\hline DI-50 & 4500 & 642.9 & 4949.6 & 98080 & 0.07 & 6866 & 1916 \\
\hline DI-75 & 4500 & 642.9 & 5268.6 & 116960 & 0.07 & 8187 & 2919 \\
\hline FI & 4500 & 642.9 & 5587.5 & 125870 & 0.07 & 8811 & 3223 \\
\hline EI & 4500 & 642.9 & 5881.3 & 125950 & 0.07 & 8817 & 2935 \\
\hline
\end{tabular}

NI - no irrigation, DI-25 - irrigation at 25\% pan evaporation (Epan) replenishment, DI-50 - irrigation at 50\% Epan, DI-75 irrigation at $75 \%$ Epan, FI - full irrigation $=100 \%$ Epan, EI - excessive irrigation $=125 \%$ Epan; ${ }^{a}-$ column numbers; 1 US $\$=$ 1.1864 TL (Turkish Lira) for 2008 year

and averaged to represent the actual water price in the study area. The cost of irrigation water was $0.15{\mathrm{US} \$ \mathrm{~m}^{-3}}^{-3}$ for farm conditions. The seasonal production cost and the drip irrigation system cost for a lifetime period of seven years were 3521 and 4500 US\$ ha ${ }^{-1}$, respectively (Kuscu et al., 2014). The total cost increased with increases in the amount of irrigation water. The net income was highest for the full irrigation treatment, followed by the EI and DI-75 treatments. Net income was dramatically decreased by increasing the severity of deficit irrigation. The lowest net income was obtained from the NI treatment where the plants were water stressed during total growing season. Therefore, these irrigation treatments (NI, DI-25 and DI50) must not be used for deficit irrigation management of silage maize in the study area. Production using these treatments would be uneconomical for the producers. This study showed that full irrigation is the best water regime to obtain a higher yield and higher net income under drip irrigation.

\section{Conclusions}

1. The selection of an appropriate irrigation schedule for silage maize production can affect the optimal forage yield potential, forage yield irrigation water use efficiency (FYIWUE) and net income, as well as some morphological characters affecting forage yield. The selection of the optimal irrigation management practice for silage maize should be based on several factors. The soil type, climate, water quality, water supply, irrigation method, fertilization, other agronomic applications and farmers' habits influence the recommended irrigation schedule. In this study, conducted under sub-humid climate conditions of Turkey, the highest forage yield and net income were obtained under fully irrigated conditions at 7-day intervals during the growing season, but the FYIWUE declined.

2 . Although excessive irrigation (EI $=125 \%$ of pan evaporation (Epan)) slightly increased forage yield, it decreased net return and FYIWUE. Therefore, EI is not recommended because of the findings of this study as well as other factors including inefficiency of water resources during summer period in sub-humid regions, vertical and horizontal erosion and soil salinity.

3. High soil water deficits resulted in severe decreases in yield and net income. However, in regions where water scarcity exists, irrigation managers and farmers should adopt the deficit irrigation approach to achieve economically sustainable crop production. As an alternative to full irrigation during the entire growing season, applying weekly irrigation at level of $75 \%$ of Epan replenishment achieved an acceptable net income with only a forage yield loss of approximately 7\% (statistically not significant) under sub-humid conditions. Based on the results of a two-year study, irrigation water savings of $25 \%$ and an increase of $16 \%$ in FYIWUE, compared with full irrigation, could be obtained with a level of $75 \%$ Epan application.

4. The irrigation scheduling with severe deficit irrigation (25\% and 50\% Epan) is not a desirable strategy under the conditions of this study.

Received 29012015 Accepted 10052015

\section{References}

Allen M., Ford S., Harrison J., Hunt C., Lauer J., Muck R., Soderlund S. 1995. Corn silage production, management, and feeding. American Society of Agronomy, $42 \mathrm{p}$.

Bozkurt Y., Yazar A., Gençel B., Sezen M. S. 2006. Optimum lateral spacing for drip-irrigated corn in the Mediterranean Region of Turkev. A gricultural Water Management. 85(12): 113-120 http://dx.doi.org/10.1016/j.agwat.2006.03.019

Carpici E. B., Celik N. 2010. Determining possible relationships between yield and yield-related components in forage maize (Zea mays L.) using correlation and path analyses. Notulae Botanicae Horti Agrobotanici Cluj-Napoca, 38 (3): 280-285

Çakir R. 2004. Effect of water stress at different development stages on vegetative and reproductive growth of corn. Field Crons Research 89(1): 1-16 http://dx.doi.org/10.1016/j.fcr.2004.01.005

Çetin Ö., Uygan D. 2008. The effect of drip line spacing, irrigation regimes and planting geometries of tomato on yield, irrigation water use efficiency and net return. Agricultural Water Management, 95 (8): 949-958 http://dx.doi.org/10.1016/j.agwat.2008.03.002

Encyclopedia of Soil Science. 2008. Chesworth W. (ed.). The Netherlands

Farré I., Faci J.-M. 2009. Deficit irrigation in maize for reducing agricultural water use in a Mediterranean environment. Agricultural Water Management, 96 (3): 383-394 http://dx.doi.org/10.1016/j.agwat.2008.07.002

Genc L., Inalpulat M., Kizil U., Mirik M., Smith S. E., Mendes M. 2013. Determination of water stress with spectral reflectance on sweet corn (Zea mays L.) using classification tree (CT) analysis. 7emdirhyste-A Ariculture, 100 (1): 81-90 http://dx.doi.org/10.13080/z-a.2013.100.011

Geren H., Avcıoglu R., Kır B., Demiroğlu G., Yılmaz M., Cevheri A. C. 2003. Effect of different sowing dates on the yield and quality characteristics of some maize cultivars grown as second crop for silage. The Journal of Agricultural Faculty of Ege University, 40 (3): 57-64 (in Turkish) 
Gheysari M., Mirlatifi S. M., Homaee M., Hoogenboom G. 2007. Water use efficiency of silage maize under deficit irrigation and nitrogen fertigation. ASA-CSSA-SSSA International Annual Meetings, New Orleans, USA

Göksoy A. T., Demir A. O., Turan Z. M., Dağüstü N. 2004. Responses of sunflower (Helianthus annuus L.) to full and limited irrigation at different growth stages. Field Crops Research. 87 (2-3): 167-178 http://dx.doi.org/10.1016/j.fcr.2003.11.004

Igbadun H. E., Salim B. A., Iarimo A. K. P. R., Mahoo H. F. 2008. Effects of deficit irrigation scheduling on yields and soil water balance of irrigated maize. Irrigation Science, 27 (1): 11-23 http://dx.doi.org/10.1007/s00271-008-0117-0

Imtiyaz M., Mgadla N. P., Manase S. K., Chendo K., Mothobi E. O. 2000. Yield and economic return of vegetable crops under variable irrigation. Irrigation Science, 19 (2): 87-93 http://dx.doi.org/10.1007/s002710050005

Istanbulluoglu A., Kocaman i., Konukcu F. 2002. Water useproduction relationship of maize under Tekirdag conditions in Turkey. Pakistan Journal of Biological Sciences, 5 (3): 287-291 http://dx.doi.org/10.3923/pjbs.2002.287.291

Iqbal S., Khan H. Z., Ehsanullah, Zamir M. S. I., Marral M. W. R., Javeed H. M. R. 2014. The effects of nitrogen fertilization strategies on the productivity of maize (Zea mays L.) hybrids. Zemdirbyste-Agriculture, 101 (3): 249-256 http://dx.doi.org/10.13080/z-a.2014.101.032

Kızıloğlu F. M., Şahin U., Kuşlu Y., Tunç T. 2009. Determining water-yield relationship, water use efficiency, crop and pan coefficients for silage maize in a semiarid region. Irrigation Science, 27 (2): 129-137 http://dx.doi.org/10.1007/s00271-008-0127-y

Kuşçu H., Demir A. O. 2012. Responses of maize to full and limited irrigation at different plant growth stages. Journal of Agricultural Faculty of Uludag University, 26 (2): 15-27

Kuşçu H., Çetin B., Turhan A. 2009. Yield and economic return of drip-irrigated vegetable production in Turkey. New Zealand Journal of Cron and Horticultural Science, 37 (1): 51-59 http://dx.doi.org/10.1080/01140670909510249

Kuşçu H., Turhan A., Demir A. O. 2014. The response of processing tomato to deficit irrigation at various phenological stages in a sub-humid environment. Agricultural Water Management. 133: 92-103 http://dx.doi.org/10.1016/j.agwat.2013.11.008

Luquet D., Vidal A., Smith M., Dauzat J. 2005. 'More crop per drop': how to make it acceptable for farmers? Agricultural Water Management. $76(2)$ : 108-119 http://dx.doi.org/10.1016/j.agwat.2005.01.011

Otegui M. E., Andrade F. H., Suero E. E. 1995. Growth, water use and kernel abortion of maize subjected to drought at silking. Field Crons Research. 40 (2): 87-94 http://dx.doi.org/10.1016/0378-4290́(94)00093-R

Overman A. R. Martin F. G. 2002. Corn response to irrigation and tillage. Communications in Soil Science and Plant Analysis, 33 (19-20): 3603-3608 http://dx.doi.org/10.1081/CSS-120015909

Pandey K. K., Maranville J. W., Admou A. 2000. Deficit irrigation and nitrogen effects on maize in Sahelian environment. II. Shoot growth. Agricultural Water Management, 46 (1): 1-13 http://dx.doi.org/10.1016/S0378-3774(00)00073-1

Payero J. U., 'Iarkalson D. D., Irmak S., Davison D., Petersen J. L. 2009. Effect of timing of a deficit-irrigation allocation on corn evapotranspiration, yield, water use efficiency and dry mass. Agricultural Water Management, 96 (10): 13871397 http://dx.doi.org/10.1016/j.agwat.2009.03.022

Rhoads F. M., Bennett J. M. 1990. Corn. Stewart B. A., Nielsen D. R. (eds.). Irrigation of agricultural crops. ASACSSA-SSSA Agronomy Monograph, 30: 569-596

Steduto P., Hsiao T. C., Fereres E., Raes D. 2012. Crop yield response to water. FAO Irrigation and Drainage Paper No. 66. Rome, Italy

Turgut İ., Duman A., Bilgili U. Açıkgöz E. 2005. Alternate row spacing and plant density effects on forage and dry matter yield of corn hybrids (Zea mays L.). Journal of Agronomy and Cron Science, 191 (2): 146-151 http://dx.doi.org/10.1111/j.1439-037X.2004.00146.x

Zhang H., Wang X., You M. Liu C. 1999. Water-yield relations and water use efficiency winter wheat in the North China Plain. Irrigation Science. 19 (1): 37-45 http://dx. doi.org/10.1007/s002710050069

ISSN 1392-3196 / e-ISSN 2335-8947

Zemdirbyste-Agriculture, vol. 102, No. 3 (2015), p. 313-318

DOI 10.13080/z-a.2015.102.040

\title{
Pusiau drègnoje zonoje silosui augintų kukurūzų derlius ir jo ekonominis efektyvumas, priklausomai nuo skirtingo lietinimo
}

\author{
A. Karasu, H. Kuşçu, M. Öz \\ Uludag universiteto Mustafakemalpasa profesinè mokykla, Turkija
}

\section{Santrauka}

Siekiant nustatyti silosui auginamų kukurūzų atsaką ị ịvairius laistymui skirto vandens kiekius, lauko tyrimai buvo atlikti 2007 ir $2008 \mathrm{~m}$. vasaromis. Tyrimo rezultatai bus panaudoti kuriant patobulintas pusiau drègnoms zonoms skirtas lietinimo sistemas. Bandymai buvo vykdyti Bursoje, Marmario regione, Turkijoje. Silosui skirtų kukurūzų veislès 'Ada-523' augalai buvo lietinami ịvairiais kiekiais vandens, molio ir priemolio dirvožemyje naudojant lašinę sistemą. Pilnai laistomi $(\mathrm{FI}=100 \%$ Epan) augalai laistyti taip, kad išgaravusi podirvinio sluoksnio drejgmė (Epan) kas 7 dienos būtu papildyta $100 \%$. Kituose variantuose buvo taikytas perteklinis (EI = $125 \%$ Epan) ir deficitinis lietinimas (DI-75 $=75 \%$ Epan, DI-50 = 50\% Epan ir DI-25 = 25\% Epan; NI - be lietinimo). Mažinant lietinimui skirto vandens kiekị augalų aukštis, pirmosios burbuolès aukštis, stiebo skersmuo, burbuolių skaičius augale ir grynosios pajamos mažèjo, tačiau vandens deficito ịtaka augalo lapų skaičiui ir burbuoliu santykiui silose buvo nedidelè. Didžiausias siloso derlius buvo gautas EI (125\% Epan), FI (100\% Epan) ir DI-75 (75\% Epan) variantuose. Didžiausias ekonomiškai efektyvus siloso derlius buvo gautas FI variante. Siloso derlių ir grynąsias pajamas abiem tyrimo metais smarkiai sumažino didelis dirvožemio drègmès deficitas. Tyrimų rezultatai parodè, kad, siekiant gauti didesnị siloso derlių ir grynąsias pajamas, turètų būti pilnai lietinama (100 \% Epan) visą vegetacijos laikotarpį. Tačiau regionuose, kuriuose yra vandens stygius, siekiant ekonomiškai tvaraus augalu auginimo, ūkininkai turi taikyti deficitini lietinimą (DI-75 $=75 \%$, DI-50 $=50 \%$ ir DI-25 $=25 \%$ Epan). Kaip alternatyvą pilnam lietinimui visą vegetacijos laikotarpi kaip optimalus rekomenduotinas DI-75\% Epan lietinimas, nes ji taikant sutaupoma $25 \%$ lietinimui skirto vandens, $16 \%$ padideja siloso derliaus lietinimo vandens naudojimo efektyvumas, augalai pasižymi geromis morfologinėmis savybėmis ir gaunamos ekonomiškai efektyvios grynosios pajamos, o derlius gaunamas tik maždaug 7 \% mažesnis, palyginus su pilnu lietinimu.

Reikšminiai žodžiai: grynosios pajamos, lašinis lietinimas, lietinimo vandens naudojimo efektyvumas, siloso derlius, vandens deficitas, Zea mays. 